\title{
Medical Humanism, a Problematic Formulation?
}

"Humanisme médical », une expression problématique?

\section{Vivian Nutton}

\section{(2) OpenEdition}

1 Journals

\section{Electronic version}

URL: https://journals.openedition.org/aes/3925

DOI: $10.4000 /$ aes.3925

ISSN: 2258-093X

\section{Publisher}

Laboratoire LISAA

\section{Electronic reference}

Vivian Nutton, "Medical Humanism, a Problematic Formulation?", Arts et Savoirs [Online], 15 | 2021, Online since 25 June 2021, connection on 17 December 2021. URL: http://journals.openedition.org/ aes/3925 ; DOI: https://doi.org/10.4000/aes.3925

This text was automatically generated on 17 December 2021 .

Centre de recherche LISAA (Littératures SAvoirs et Arts) 


\title{
Medical Humanism, a Problematic Formulation?
}

«Humanisme médical », une expression problématique?

\author{
Vivian Nutton
}

1 Almost fifty years ago, the great Paracelsian scholar Walter Pagel wrote a challenging chapter at the end of a volume of essays on Thomas Linacre (c.1560-1524), translator of Galen and Proclus, author of school texts on Latin grammar, and leading spirit in the foundation of the London College of Physicians in $1518^{1}$. In it, he argued strongly that medical humanism was what he termed a "historical necessity in the era of the Renaissance", by which he meant that, in some way, the renewal of interest in the ancient classics, and particularly in Galen, in the fifteenth and sixteenth centuries was an essential stimulus to the development of new ideas in Vesalius, Paracelsus, and Harvey. It was a typical Pagel essay, learned and allusive at the same time, and demanding that historians judge authors without the benefit of hindsight even if their ideas were hardly consonant with those of modern medicine. Not for nothing was one of his favourite pieces entitled "The Vindication of 'Rubbish"'. But, at the same time, the reader cannot help but worry about the laxness of a term that can cover almost two centuries and authors as different as Leonhard Fuchs (1501-1566) and Sanctorius Sanctorius (1561-1636), let alone Paracelsus (1493-1541), and can apply equally to a general education and to a belief in specific ideas and practices. This article aims to tease out some of the overlapping meanings of the term as it is used by modern historians, and to further explore some of the context of the relevant renaissance debates about humanism and its relationship to learned medicine.

2 At its loosest, medical humanism may be defined as the prioritising within medicine of ideas and practices that not only derived from Classical Antiquity directly without the mediation of medieval or Islamic authors, but also were part of a more general culture that looked back to the Romans and Latin authors for moral guidance as well as stylistic improvement. Originally centred on Northern Italy, Rome, and Naples, it spread relatively slowly across the Alps, and may have been confined there to small elites until the development of new types of school, gymnasia or grammar schools, that taught the 
new humanist curriculum at the end of the fifteenth century or even later in Britain. Yet, for a long time, it scarcely impinged on medicine. Rejoicing greeted the discovery of an ancient codex of Celsus' De medicina in Siena in 1426 and of another equally venerable codex in Milan three or four years later, and numerous copies survive that were taken from them before $1500^{3}$. But it is hard to discern any great impact on medicine even after the first printing in 1478, or of another Latin author on medicine, Quintus Serenus, whose poem on medicine was printed in 1484. The Swiss humanist Joachim Vadianus (1484-1551) thought of lecturing on Serenus in Vienna in 1516, but it is not clear that he ever did so ${ }^{4}$. More significant, because of the size of his medical books and his wider appeal, was Pliny the Elder (23/4-79), whose Historia Naturalis was often read, and even lectured on in Leipzig around 1514, not least because of the abundant material of herbs and other drugs it contains ${ }^{5}$. Doctors long continued to rely on much earlier translations of Galen into Latin, consolidated in print in the 1490 edition of the Latin Opera omnia Galeni. Learned late-medieval professors like Jacques Des Pars in Paris (1380-1458) knew their Latin Galen, and doctors like Giovanni di Marco (d. 1474) in Rimini, Hartmann Schedel (1440-1514) in Munich, and Guillaume Poirier (fl. 1480) in Paris were keen to own a complete Galen in manuscript ${ }^{6}$. Printing made this material much more widely accessible, and the issuing of new editions of the Opera Omnia attests to an eager market of wealthy buyers. But, like so much else in fifteenth-century medicine, our understanding of this Latin humanism is at best partial, and heavily dominated by the familiar story of Leoniceno, his pupils, and his opponents in the Plinian controversy at the very end of the century.

That controversy, as more than one recent scholar has pointed out, was not a simple confrontation between philologists and medics, for they could be found on both sides of the argument, and Leoniceno was not the only participant who both knew Greek and had a practical knowledge of plants. Equally significant was the controversy in 1502-1503 between Alessandro Benedetti (c.1440-1512) and Gabriele Zerbi (1445-1505) over anatomy. Both men came from similar backgrounds, worked in Venice and Padua, and were roughly the same age. Benedetti's book on anatomy was provocatively titled Anatomice and was printed in the most elegant Roman typeface ${ }^{7}$. He knew Greek and had a small library of Greek manuscripts, none of them medical, but for all its claims, his book does little more than update the language of anatomy, following Leoniceno and Giorgio Valla (d. 1499) into a more classical form. It was vigorously attacked by Zerbi in his commentary on Mondino's Anatomy. Benedetti's book in all its aspects was aimed a broad cultivated public, whereas Zerbi wrote his much longer exposition for practitioners. In it he emphasised his own long experience in dissecting, surgery, and performing autopsies, and proclaimed the merits of his knowledge of the body over mere book learning ${ }^{8}$. Printed in double columns with abbreviations and ligatures, the book's very appearance proclaimed its medieval heritage, and was so familiar to doctors that the 1517 Pavia reprinting of Benedetti reintroduced ligatures in a hybrid medievalisation. Zerbi's grisly death at the hands of Albanian brigands called forth unjustified jibes that this prize mutilator of human bodies had met a suitable fate.

4 This Latin humanism, promoted by individuals with little or no Greek themselves, lasted arguably until the 1530s. It has been little studied in favour of that of the Hellenists, as Roger French called them, despite the fact it was practised by most medical practitioners even in some of the best universities. Its proponents eagerly seized on new translations of the Greek into Latin, but until the late 1520s these were almost always simply more accurate and, in terms of the Latin, more elegant versions 
of standard university texts. Not until May 1526 when Erasmus produced his versions of three small Galenic treatises that appealed to a non-medical audience was a Galenic work printed that had not been included in the 1490 and subsequent editions of the Latin Opera Omnia. The Salzburg physician Leonhard Schmaus was justified in his complaint to his friend Vadianus in 1519 that however much one might hope to see Greek authors turned into Latin and widely accessible, and however much one might accept that one could gain more solid learning from a day's reading of Galen than from a whole week of Avicenna, Schmaus and those like him with little or no Greek could do nothing if editions of Galen, in Greek or in Latin, were few and far between, and available only in isolated centres like Vienna and Augsburg9.

Schmaus's complaint does not lack foundation, and its implications have never been properly teased out ${ }^{10}$. Apart from revisions of Galenic treatises in the Latin Opera omnia and a small selection of Hippocratic texts in the Articella, only a tiny handful of Greek medical texts had appeared in Latin translation at the time, and one, an abridgement of Joannes Acutarius' big book on urines, had only just appeared ${ }^{11}$. Most of the rest had appeared in 1498 in an unusual collection of translations from the Greek by Giorgio Valla and, one, of the pseudo Galenic De succedaneis, by Giovanni Pietro Valla ${ }^{12}$. This large folio volume included, alongside non-medical texts, Alexander of Aphrodisias's On Fevers, Rhazes's On Plague, some minor Galenica, and a work ascribed to Psellus, De victus ratione (but now known to be by the even more obscure Theophanes Chrysobalantes) ${ }^{13}$. The last tract was a short guide to dietetics, typical of many renaissance productions, and it is not surprising that within a matter of months it was re-printed at Erfurt in a co-operation between the university's professor of medicine, Georg Eberbach (d. 1492) and its professor of Arts, Nicholaus Marschalk (d. 1525) ${ }^{14}$. Aimed at beginners in Greek as well as at young doctors, it was provided by Marschalk with a small commentary in which he explained the new humanist terms used by Valla and provided identifications for the plants named along the lines newly laid out by Leoniceno. Marschalk also inserted occasional Greek words - a very early instance of Greek printing in Germany. Erfurt was among the main centres of humanism in Germany, and this re-appropriation of the classics was typical of the activities of some of its teachers. But it was a Latin humanism, best seen in the (now lost) ceiling of the so-called museum of another medical professor, Georg Sturtz (1490-1548), which was decorated with portraits of famous medical men of Antiquity, all derived from Pliny's Natural History ${ }^{15}$.

Guillaume Cop's version of a similar section on dietetics by Paul of Aegina had greater success, being re-printed five times before 1528 (three times in Paris, once in Strasbourg, and once in Nuremberg), which suggests that there was a market for practical texts from Antiquity. But, before 1526, publishers were reluctant to publish humanist medicine or, what may be more likely, authors were reluctant to appear in print. Leoniceno himself published a series of short texts correcting traditional interpretations of Galen and Dioscorides, but his only primarily medical text was his often-reprinted little book on the French disease, in which he argued that it had existed already in Antiquity, and that appropriate therapy could be found in classical authors. His pupil, Giovanni Manardi (1462-1536) did not publish the first series of his Epistolae medicinales (Medical Letters), arguably the most influential of the Hellenists' practical publications, until 1521. Instead, printers re-issued as practical manuals the books of professors and clinicians of the fifteenth century, by Jacques Des Parts, Marco Gatinaria (d. 1496), Antonio Cermisone (d. 1441), and Bartolommeo di Montagnana (fl. 14221460). There is one major exception: the prolific Symphorien Champier, discussed in 
this issue by Caroline Petit. Champier was the author, among other things, of a Practica, derived from "the traditions of the Greeks, Latins, Arabs, Carthaginians and modern authors" that was published around $1510^{16}$. But his singularity as an author of Latin Humanism has until now hampered a proper understanding of what he was doing and how he went about doing it. To what extent he knew Greek is a crucial question, although it is one that is difficult to answer. He did not own Greek manuscripts, and his Galenic material apparently derives almost entirely from works already included in the Latin Opera omnia. Given that Galen's Platonism was not fully made known until after 1526 at the earliest, and unless he was informed through intermediaries such as Ficino, the celebrated frontispiece of his Symphonia - avowedly bringing together Galen, Hippocrates, Aristotle, and Plato - is a much a piece of exaggerated advertising as his earlier description of his Practica.

7 This stage of medical humanism lasted until the late 1520s, when the great flood of Latin translations of Galen and Hippocrates made available to those without Greek previously unknown or neglected material. Although more people could read Greek, and publishers were willing to experiment with small volumes in Greek (or to include a small Greek treatise at the back of a volume containing more saleable Latin translations, as was the case with Rabelais' edition of the Aphorisms), Latin continued to be the main language of scholarly discourse ${ }^{17}$. The plan of the Basle cleric and university reformer Oecolampadius (1482-1531) in 1529 to appoint Simon Grynaeus (1493-1541) to the chair of Greek and for him later to join the medical Faculty and lecture on Galen and Hippocrates in Greek seems never to have been followed through, although employment of someone to teach Greek was regarded as a possibility in the Statutes of $1533^{18}$. As a result, it continued to be through the medium of Latin translation that most physicians were enabled to participate in intellectual discussions about Galen and their ancient heritage. Latin versions of classical texts sold more widely, even if some of the later Juntine editions of the Latin Omnia Opera have been rightly suspected of being re-issues of earlier editions that had failed to sell and were now given a new title page. Even when a Greek text was available alongside a Latin version, purchasers tended to read the Latin. William Harvey will not have been the only scholar to solely annotate the Latin side of a bi-lingual edition, and a correspondent of Mercuriale who earnestly hoped that his great edition of Hippocrates would include a facing version was probably not alone in this hope ${ }^{19}$. But although physicians at the end of the sixteenth century still played a full part in the wider manifestations of humanism, including the writing of history and elegant verses, and, on the whole, still trusted in the wisdom of Antiquity, Latin medical humanism differed substantially from what it had been in $1530^{20}$.

8 This shift was almost entirely the result of the arrival of more Greek medicine, first in manuscripts in Northern Italy from the 1460s, and then in printed form in the original Greek or in translation from $1525^{21}$. Although the basis of university lectures remained largely the same as in the Middle Ages, the so-called Articella texts supplemented by Galenic texts that had been included in the late Antique syllabus, plus sections from Avicenna and Rhazes, these were now viewed within a different context. The new Greek texts offered previously unknown insights into Galen's physiology, philosophy, methods of commentary and, above all, anatomy. But equally important was the realisation that Galen had been far more empirical than the old summaries had suggested, and that his enormous oeuvre was filled with contradictions, not all of which had been systematised away by Avicenna and his Arabic colleagues. The new 
Greek medicine was both broader in scope than its predecessors, it stimulated new arguments and new thoughts on central aspects of medicine, from anatomy and methods of diagnosis to understanding plague.

9 The protagonists of this Hellenised medicine can be located along a broad spectrum ranging, at one end, from medics with little or no recourse to the original Greek but who accepted and developed the new discoveries, to those for whom knowledge of Greek was essential. "Without Greek", said Jan van der Velde, "All medicine is mere imposture"22. Before 1525, most of the Hellenists concentrated upon the significance of words, whether translating Greek texts into a more modern and more accurate style or attempting to clarify a confusing number of Latin terms that were used in medicine to apply to the same thing. Leoniceno in 1492 had shown the way by revealing the many errors of Pliny and the Arabs in mis-identifying or mis-labelling plants because of their ignorance or their misunderstanding of the original Greek from which their information came. This confusion was only to be expected, given the complex way that most ancient Greek medicine and botany had reached the Renaissance West in Latin, either directly translated in word-for-word versions with many transliterations or indirectly via Syriac, Arabic, and Hebrew intermediaries. Leoniceno himself in many short essays had demonstrated that a proper grasp of the original Greek of Galen or Dioscorides resolved many of the puzzles that had troubled medieval interpreters. In his Medical Letters, Giovanni Manardi followed his teacher Leoniceno's example by including lexical accounts of internal worms, internal and external diseases, as well as those of individual plants ${ }^{23}$. In a programmatic opening Letter, he declared that medicine was impossible without a proper grasp of terms, and that in his lectures at Ferrara he had insisted that this should be the priority of all his pupils ${ }^{24}$.

Such terminological investigation was a feature of much medical writing throughout the sixteenth century, visible especially in commentaries on Galen and Hippocrates as well as in writings on medical botany. Leoniceno had concentrated on identifying the plants mentioned in Dioscorides and Pliny, and his successors had the task of extending these correlations to local languages and to local flora, particularly those beyond the Alps. Major books on medical botany, like those of Pietro Andrea Matthioli (1500-1577), listed many names for each plant so that investigators would be able to use local information as well as their classical texts. It was not only doctors who did this. An educated amateur, Gherardo Cibo (1512-1600), added local names that he had himself found to the headings in the drawings of plants that he had read about in Matthioli ${ }^{25}$. Comparison between variant translations was also standard in learned commentary, with occasionally variant versions of the same text printed alongside or in sequence in the same volume. Some of these terminological debates became very heated. Antonio Musa Brasavola (1500-1555), the successor to Leoniceno and Brasavola at Ferrara, described a vigorous dispute in print between his predecessors over the correct translation of a word in Hippocrates as two old men making a mountain out of a molehill, ex musca elephantum ${ }^{26}$.

11 Commentaries continued for centuries more, especially where there were set texts like the Aphorisms, but from the 1550s, as with those of Giambattista da Monte (1498-1552) in Padua, they concentrated more on medical than on philological points. An exception can be made for commentaries that accompanied editions of the Greek or, as with some of the Paris commentaries on Hippocrates (such as Houillier's commentary on Coan Prognoses), were effectively elucidating a text for the first time, where a great attention 
to philological details was called for ${ }^{27}$. Otherwise, such philological discussions of points in medical texts became rare and were confined to collections of Observations, like those of the papal physician, Marsilio Cagnati (1543-1612), which resembled those of specialists in Latin and Greek literature ${ }^{28}$.

The publication of the Aldine edition of Galen in 1525 confirmed, for the most part, the claims of the Hellenists for the superiority of the Greek originals to their later manifestations for both their accuracy and their range of new information. But it quickly became obvious that this edition contained many flaws, from simple copying mistakes to a large gap in one treatise where the printer's candle had fallen on to the page when he fell asleep over his work. Erasmus blamed it all on the Aldine firm's unwillingness to pay for a competent editor, and instead employing inexperienced young men from Northern Europe. This was perhaps unfair for one of the editors, John Clement, was among the finest Greek scholars in Europe, and the many emendations he passed on to the editors of the 1538 Basle edition made great improvements to the next. The annotations in his copy of the Aldine, now in Leiden, or those that were passed on to his friend John Caius, were not improved upon until the late nineteenth century ${ }^{29}$. Modern scholars have also studied the emendations of other annotators of Hippocrates and Galen, including Saxon Janus Cornarius and John Caius ${ }^{30}$. Many others remain to be discovered among marginalia or have been lost. One wonders, for example, what became of the huge volume of notes left by Georg Agricola (1494-1555), the editor of the Aldine Hippocrates.

13 These annotators had also developed a sophisticated methodology in their editions. They collated whatever Greek manuscripts they could find. John Caius spent months travelling around Italy visiting libraries in search of Greek manuscripts, and on his return to England also copied into his margins many readings provided by English friends, including John Clement and Edward Wotton, two of the editors of the Aldine Galen. Antonio Gadaldino, who was in charge of the editorial side of the later Giuntine editions of the Latin Galen, provided his collaborators, including Vesalius and Caius, with Greek manuscripts and annotations for them to check and, if possible, use to improve the accuracy of the Greek text they were translating. The editors of the Basle 1538 edition of the Greek were not alone in inspecting previous Latin translations, including those by Thomas Linacre, as a way of discovering new and better readings.

The results were not always satisfactory. Manardi had already concluded that almost all the known manuscripts had flowed "ex una velut fonte" ("as if from a single source") - a pardonable exaggeration in its context, with its implication that any improvements from collations would be minor ${ }^{31}$. Most annotations remained in the margins of personal copies, and their value was subject to the law of diminishing returns. Many were little more than simple proof corrections, and the greatest Greek scholar of the age, Joseph Justus Scaliger, was scathing about the linguistic capabilities of the Parisian doctors who attempted to edit and translate Hippocrates ${ }^{32}$. Nor was there an abundance of new classical material. John Caius published a few small pieces of Galen, and the publication in 1552 of Crassus's Latin translation of selected minor authors made them available to those without Greek. The most prominent of the discoveries after the Aldine edition was that of Galen's On Bones (about which see Allen Shotwell's contribution in this volume), which went through many printings in Latin and was used as the basis for anatomical teaching in some universities, even though it was far less accurate than more modern books. It was, however, far better adapted than they for 
university teaching, being short, comprehensive and with an appropriate classical pedigree.

This "philological" Hellenism, it should be remembered, was the preserve of only a handful of practitioners, whose names could all be included in a single brief paragraph, and although scholars of the calibre of Erasmus and Scaliger dabbled in it, its most famous names, and certainly its most prolific translators, Guinther von Andernach and Johannes Rasarius, do not rank high in the pantheon of Renaissance scholars ${ }^{33}$. They were far more celebrated for the quantity of their versions than their quality. Most practitioners, however, did not concern themselves with philology beyond what the Hungarian humanist, Andreas Dudith (1533-1589), termed a "prejudice in favour of Antiquity": the belief that a tradition of medicine that had behind it two millennia of apparent success was not to be discarded lightly, especially when some of its medieval accretions had been removed and its most important texts had been correctly interpreted $^{34}$.

This purified tradition is what Pagel had in mind in his challenging essay when he attributed such importance to medical humanism. But as with humanist philology in general, many different attitudes can be seen ranging over several centuries, for many features of this tradition long remained significant even as others disappeared. The classical therapeutics of the sixteenth century were still highly regarded in the nineteenth and were one of the reasons behind the major editions of Galen by Cart Gottlob Kühn (1821-1832) and of Hippocrates by Emile Littré (1839-1863). But the doctrine of humours had been largely forgotten in learned circles by the end of the seventeenth century, replaced by iatrophysics, iatrochemistry, and a variety of other theories. The adherents of this tradition in the late sixteenth century frequently defined themselves against Epicureans, believers in a materialist universe in which teleology and divine purpose played little or no part, and against Paracelsians, whose emphasis on the chemical transformations of the body was allied to revolutionary ideas about spirits and the inward light. But there were also many, like Conrad Gessner, himself no friend of Paracelsians, who saw value in their chemical drugs, or like Vesalius' teacher, Guinther von Andernach, who produced a synthesis of the old and new medicine. The dark sayings of Hippocrates also offered the possibility of an explanation in Paracelsian terms, as Thomas Mouffet (1553-1604) argued in his Nosomantica Hippocratea, Hippocratic Prognosis of $1588^{35}$.

17 At the other extreme were those who founded their writings on a detailed accumulation of texts drawn from across antiquity either, like Leoniceno, to show that solutions to current problems such as plague could be found centuries earlier, or, like Girolamo Mercuriale (1530-1606), to produce innovative studies of poisons, paediatrics and much else. Mercuriale's masterpiece, his De arte gymnastica, proclaimed the importance to health of physical exercise, combining ancient evidence from ancient religious, historical, literary, and medical authors as well as from archaeology and epigraphy $^{36}$. Others, like Jean Fernel (1497-1558) in his Medicina, did little more than update the medieval syntheses of Avicenna and Haly Abbas by adding Galenic material that had been previously unknown ${ }^{37}$. The debate about the value of Arabic medicine had not been settled by Leoniceno in 1492. Many doctors accepted that Arabic writings contained much valuable information on more drugs and recipes than were available in Antiquity, while accepting the need for caution in identifying the substances involved. Avicenna, as Nancy Siraisi showed, long continued as a set text, and the translation by 
the Bolognese professor Giovanni Costeo (d. 1603) and subsequent editions and commentaries, including the editio princeps of the Arabic in 1593, used the methods of the Greek philologists to produce a more precise and reliable text for physicians ${ }^{38}$.

At the same time, other institutions rejected these medieval set texts in favour of more classical ones. For over a century after its foundation in 1518, the London College of Physicians based its examination for entry of a detailed knowledge of the works of Hippocrates and Galen, a test that most of today's specialists in ancient medicine would have difficulty passing. A variety of German universities changed their statutes to include only classical texts in Latin translation, although, significantly, Freiburg and Ingolstadt were not alone in reverting to medieval texts in the later sixteenth century ${ }^{39}$. But lecturing on set texts was inherently flexible, for these were intended only to inculcate principles and the latitude allowed to any lecturer was considerable. For a similar reason, Parisian interest in Hippocratic texts allowed teachers there to range widely in interpreting these novel books while at the same time retaining the cachet of representing a centuries long tradition.

What is less clear is the impact that Greek texts had on the practice of medicine and on medical education. They provoked learned discussed on specific points, such as whether it was better to bleed from close to the site of the illness or swelling or from the opposite side of the body. Other changes could easily be accommodated within a traditional framework. The theory of Girolamo Fracastoro (1479-1553) - that contagious diseases were spread by seeds or seed beds (seminaria) transmitted in the air, by contact, or at a distance by fomites - could easily be adapted to prevailing notions of bad air. Debate centred far more on whether what was transmitted worked by putrefaction, poison, or some Aristotelian sympathy or antipathy than on any idea of the specificity of diseases ${ }^{40}$. But physicians were moving away from strict Galenic theory as it had long been taught. Giambattista Da Monte, the most significant of Paduan Galenists, reinterpreted the Galenic method as it was expounded in the shorter Method of Healing to demand a careful examination of all the patient's symptoms. Autopsies were becoming more frequent, and emphasis shifted from a determination of the patient's humoral balance towards a concentration on individual symptoms and the careful recording of diseases ${ }^{41}$. From the 1560s onwards, more and more writers published their Observationes, sometimes, as with Pieter van Foreest, "the Dutch Hippocrates," accompanied by a lengthy and erudite commentary based upon classical sources ${ }^{42}$.

The development of anatomy is regularly seen as overthrowing the Galenic system on which it had been based. After the initial enthusiasm at the restoration of a practice that had been generally neglected by physicians - the ordered dissection of a human body - dissectors quickly began to notice discrepancies between what Galen had said. Andreas Vesalius, in his De humani corporis fabrica (1543), went further by claiming that these discrepancies were not minor, the fault of corrupt texts or translations or the result of anomalies, but systematic, the consequence of Galen's reliance on animal dissection. His mantra that one should investigate the human body solely on the basis of human dissection, combined with his belief in the superiority of what could be seen over the written word, has earned him the praise of subsequent anatomists. Indeed, writing in 1566, Theodore Hagecius - later to achieve fame as an alchemist-physician at the court of Emperor Rudolf II - could compare him, in passing, with Copernicus for daring to challenge the erroneous ideas of the ancients. ${ }^{43}$ 
21 But, as recent scholars have shown, to think in terms of a rejection of Galenism or a stubborn conservatism is to mistake Vesalian rhetoric for reality. Rumours began circulating within weeks that Vesalius had misrepresented both Galen and many contemporaries who had reached the same conclusions as he, and Niccolò Massa was right to draw attention in print to his priority over his one-time pupil, even if the exact details of what he had taught remain obscure ${ }^{44}$. Vesalius was a superb dissector, but he was far from alone in making discoveries, and Colombo, Canani, and Falloppia - to name but three of the younger anatomists - did not need Vesalius to tell them how to use their eyes. Besides, his plea for sole reliance on human anatomy was impossible to attain - there were not enough human bodies to go round - and contradicted by his own practice and by the Fabrica itself, where a plate showing an animal prepared for dissection is placed discreetly towards the back of the large volume ${ }^{45}$. Autopsies might supplement the evidence of human bones, but the workings of the living body could be effectively studied only from animal vivisection.

Galenists too were divided in their immediate response to Vesalius. His old master, Guinther, accepted all the corrections Vesalius had made in his unauthorised 1538 revision of his anatomical textbook "according to Galen" when, assisted by Servetus, he brought out his own revision in 1539, going further than Vesalius in his criticisms of Galen $^{46}$. There were a few Galenists who responded immediately by a vigorous denial of almost everything Vesalius had said in the Fabrica. Caius and Cornarius rightly pointed to Vesalian misunderstandings of Galen's Greek, but few went as far or so abusively as Jacobus Sylvius in his denunciation of all for which Vesalius stood. Even the claim that the Roman body had changed over the centuries since Galen had described it would have appeared far from ludicrous in a society where the results of breeding dogs and horses were familiar ${ }^{47}$. Besides, it is no coincidence that those who criticised Vesalius most harshly and who complained about the unfairness, some said impiety, of his assault on Galen were those who had known him personally in Paris or Padua and who had not forgotten the ways in which he had disguised his obligations to others and, in his revision of Guinther's book, exalted his own discoveries over that of his master. His many laudatory references to Galen in the Fabrica were often taken as tokens of his insincerity, especially as they were often followed by severe qualifications.

Others, however, took these references as evidence that Vesalius was continuing what Galen had himself wished but was unable to achieve. Melanchthon in Germany, the most humanist of Lutherans, carefully read his copy of the Fabrica from cover to cover, even writing a poem in its praise. Aided by his friend Leonhard Fuchs (1501-1566), professor of medicine at Tübingen and a noted Galenic scholar, he revised his major textbook On the Soul in 1552, replacing Benedetti's anatomy with that of Vesalius. Wittenberg professors of medicine eagerly annotated their copies of the Fabrica, one at least presented by Vesalius himself, and spread his message throughout the Germanspeaking world ${ }^{48}$. Similar enthusiasm has been shown among the younger Spanish anatomists, who were keen to introduce dissection into their universities, and even in England ${ }^{49}$. The Fleming Thomas Geminus published in London in 1545 many of the images in Vesalius' Fabrica and Epitome in his Compendiosa totius anatomiae delineatio (An All-embracing Sketch of Anatomy), with the approval of none other than Henry VIII, to the annoyance of Vesalius, who complained that had he asked permission, he would have been willing to loan him the original blocks. Most striking as an example of the coexistence of Vesalius and Galen is a comment by a Cambridge Arts don, Christopher 
Langton (1521-1578), who went on to study medicine and become a Fellow of the London College of Physicians. In 1545, he began his English survey of medicine, An Introduction into Physicke, with some thirty pages describing the human body in Galenic terms, deriving possibly from Benedetti. Two years later, he produced a substantial revision, A Very Brefe Tretise Ordrely Declaring the Principal Partes of Physick, in which he abolished the original anatomical section, replacing it with a simple sentence: "whoso is willing to have a particular rehearsal of all the parts, let them seek Galen or Vesalius. For they have written whole books and great volumes of them" ${ }^{50}$. Whether he had done more at this point than see a copy of the Fabrica is unclear, but he certainly did not regard them as incompatible. Even John Caius, at least in print in 1570, was compelled to acknowledge Vesalius' importance, playing up his earlier association with the great man and suggesting a greater agreement between them than was the case. He still rejected many new discoveries, but these "errors" he ascribed to other anatomists such as Colombo ${ }^{51}$.

There were some who preferred to stay with Galen for teaching purposes even into the next century. Most influential was the Spanish doctor, Luis Mercado (1520-1606), who, as chief physician of the realm, imposed his own Galenist writings as set books throughout Spain, and banned Vesalian anatomy in favour of Galen's On the Usefulness of Parts. His dislike of Vesalius extended to denying that there had ever been Vesalians in Spain, although there had been for at least a generation at his own university, Valladolid ${ }^{52}$. His argument was simple: Galenic functional anatomy and physiology was more relevant to medical practice than descriptive anatomy. It was an argument that was also heard in several German universities that introduced or reverted to the same Galenic text after some years of experimenting with Vesalius ${ }^{53}$. The same argument was used even in Padua and Bologna, where as late as 1679 Paolo Mini, the professor of anatomy, recommended it in favour of dissection, which he thought suitable only for mechanics and irrelevant to the future practice of physicians ${ }^{54}$.

What can be seen from the 1540s onwards is an adaptation of Galenic medicine, in exactly the same way as Dioscoridean pharmacology was extended and surpassed by the medical botanists at the end of the century. They acknowledged their classical heritage, and they often followed Dioscorides' methodology in investigating the plants of the regions that he and Galen had never known, but ultimately the amount of new information far outstripped the template of a commentary on Dioscorides that had won Matthioli his reputation in the 1540s and 1550s. The so-called "new diseases" of the sixteenth century - whether they came from beyond Europe, as some believed syphilis to have done, or from regions scarcely visited by Greek doctors, like the English Sweat or the Moravian Plague - acted as catalysts for change, even if modern doctors continued to refer to Galen and Hippocrates for advice about how to respond to them.

Medical humanism, as this article has argued, is as fluid and unreliable a term as humanism itself. At its narrowest, a strict adherence by most physicians to the tenets of ancient Greek physicians, the medical equivalent of humanist Ciceronianism, lasted little more than a generation, from the 1520s to the 1550s. Even so, two of its leading exponents, Leoniceno and Manardi, refused to teach the medical skill of which Galen was most proud, prognosis, which they regarded as guesswork and as worthless as astrology ${ }^{55}$. Before the 1520s, an acquaintance with Greek medicine in its pure form unmediated by medieval systematisers was confined to a handful of practitioners, many of whom were also involved in other areas of humanist learning. After the 1550s, 
new ideas, new techniques, and new experiences could be added to a classical foundation without challenging one's adherence to a hellenised medicine. As Adam Landau put it in 1566, "We rely on Galen, but no one should just blindly accept authority, no matter however distinguished, and retail falsehood" 56 .

Indeed, the rise of Paracelsianism led only to more strident attacks on those who rejected this ancient learning and to further demands for consolidation against this dangerous 'other' that threatened to introduce religious as well as medical heresy into the Christian community. Where one draws the line between different types of medical humanism is a matter of personal choice. One can point to the remarkable changes brought about by the arrival of the new Galen in Latin translation after 1520 as an indication of the power of these ancient texts to stimulate debate and new ideas, or, like David Wootton, dismiss them entirely as worthless ${ }^{57}$. But, at the very least, one should be careful about using the term "medical humanism" and, wherever possible, set out precisely how it is to be understood. Even if not a medical necessity, it may still remain a useful description for medical historians to employ.

\section{NOTES}

1. Walter Pagel, "Medical Humanism - a Medical Necessity of the Era of the Renaissance', in Francis Maddison, Margaret Pelling \& Charles Webster (eds), Essays on the Life and Work of Thnomas Linacre c. 1460-1524, Oxford, Clarendon Press, 1977, p. 375-386.

2. Walter Pagel, "The Vindication of "Rubbish", reprinted as essay I in his Religion and Neoplatonism in Renaissance Medicine, London, Variorum Reprints, 1985.

3. Karl F. C. Marx (ed.), A. Cornelius Celsus, De Medicina. Corpus medicorum latinorum, Leipzig, Teubner, 1915, pref.

4. Bernhard Milt, Vadian als Arzt, St. Gallen, Fehr'scher Buchhandlung, 1959, p. 21-22.

5. Charles G. Nauert, "Humanists, Scientists, and Pliny: Changing Approaches to a Classical Author", The American Historical Review, vol. LXXXIV, 1979, p. 72-85.

6. For Poirier as the commissioning owner of Dresden, Sächsische Landesbibliothek Db, p. 91-92, Vivian Nutton, "Picturing Medicine: the Dresden Codex", in Karin Krause \& Barbara Schellewald (eds), Bild und Text im Mittelalter, Cologne, Weimar and Vienna, 2011, p. 347-361.

7. Alessandro Benedetti, Historia corporis sive Anatomice, Venice, B. Gueraldo, 1502; Giovanna Ferrari, L'esperienza del passato. Alessandro Benedetti, filologo e medico umanista, Florence, L. S. Olschki, 1966; Alessandro Benedetti, Historia corporis sive Anatomice, Florence, Giunti, 1998.

8. Gabriele Zerbi, Liber anathomia corporis humani et singulorum membrorum illius, Venice, B. Locatello, 1502; Roger K. French, Dissection and Vivisection in the European Renaissance, Aldershot and Brookfield VT, Ashgate, 1999, p. 81-91.

9. Ernst Arbenz, Die Vadianische Briefsammlung der Stadtbibliothek St. Gallen, II. Mitteilungen zur vaterländischen Geschichte, vol. XXV-2, 1891, p. 248.

10. Useful background in Gerhard Baader, 'Mittelalter und Neuzeit im Werk von Otto Brunfels', Medizinisches Journal 13, 1978, 186-203; Medizinisches Reformdenken und Arabismus im Deutschland des 16. Jahrhunderts', Sudhoffs Archiv, vol. LXIII, 1979, p. 261-296. 
11. Joannes Actuarius, De urinis libri septem de Graeco sermone in Latinum conversi, Venice, B. Vitalis, 1519.

12. Giorgio Valla, trans., Nicephorus, Logica......Venice, S. Bevilacqua. Fragments of Paul were included in Valla's De expetendis and in Guillaume Cop's Pauli Aeginetae praecepta salubria, Paris, H. Estienne, 1510. I deliberately exclude translations of Dioscorides.

13. Joseph A. M. Sonderkamp, Theophanes Chrysobalantes, Bonn, R. Habelt, 1987, p. 1-6.

14. Psellus, De victus ratione, Erfurst, W. Schenck, 1499. For details, Vivian Nutton, "Hellenism postponed: some aspects of Renaissance medicine, 1490-1530", Sudhoffs Archiv, vol. LXXXI, 1992, p. $158-170$.

15. Nutton, op. cit., 167-169.

16. Symphorien Champier, Practica nova, Lyons, n.d.

17. François Rabelais, ed., Hippocratis ac Galeni libri aliquot, Lyon, S. Gryphius, 1532, the best seller among Rabelais books.

18. Albrecht Burckhardt, Geschichte der medizinischen Fakultät zu Basel 1360-1900, Basle, Friedrich Reinhardt, 1917, p. 34, p. 133-134.

19. Vivian Nutton, "Harvey, Goulston and Galen", Koroth, vol. VIII, 1985, p. 112-122.

20. Douglas Biow, Doctors, Ambassadors, and Secretaries: Humanism and Professions in Renaissance Italy, Chicago and London, The University of Chicago Press, 2002; Nancy G. Siraisi, History, Medicine, and the Traditions of Renaissance Learning, Ann Arbor: University of Michigan Press, 2007; the theme of medical poetry in the context of polite exchange merits further attention. I have not seen Pascal Pia, Bouquet poétique des médecins, chirurgiens, dentistes et apothicaires, Paris, Collection de l'Écritoire, 1933, which may deal only with French authors such as René Bretonnayau, La Generation de l'homme, et le Temple de l'âme avec Autres oeuures poëtiques extraittes de l'Esculape de René Bretonnayau Medecin, natif de Vernantes en Anjou, Paris, Abel, L'Angelier, 1583, and not with minor Latin poets such as Johann Moninger (c. 1524-1584), Otto Clemen, "Joh. Moninger, Poet, Historiker, Arzt, Apotheker und Archivar", Zeitschrift für bayrische Kirkengeschichte, vol. XIII, 1938, p. 215-223.

21. Dioscorides is a minor exception being printed in Greek in 1499 , but botany was a subject that attracted a wider interest than medicine itself. For Galen, see now Stefania Fortuna, "Editions and Translations of Galen from 1490 to 1540", in P. Bouras-Vallianatos \& B. Zipser (eds), Brill's Companion to the Reception of Galen, Leiden and Boston, Brill, 2019, pp. 437-452.

22. Jason van der Velde (Pratensis), De pariente et partu. Antwerp, s.n. 1527.

23. Giovanni Manardi, Epistolae medicinales III-1 and IV-1: VII-2,3; IX-3 and 5: in aa.vv. Epistolae medicinales diversorum authorum, Lyon, heirs of J. Junta, 1556, p. 11-12 and 15-17; 43-59; 102-108.

24. Ibid., Ep. II-1, p. 6.

25. Giorgio Mangani \& Lucia Tongiorgi Tomasi (eds), Gherardo Cibo: Dilettante di Botanica e Pittore di "Paesi", Ancona: Il lavoro editoriale, 2013.

26. Antonio Musa Brasavola, In octo libros Aphorismorum Hippocratis et Galeni, commentaria \& annotationes.... Basle, Froben, 1541, p. 407.

27. Jacques Houiller, Coaca praesagia, Lyons, G. Rouille, 1576. A new commentsry on the same text was published by Louis Duret, Paris, D. Duval, 1588.

28. Marsilio Cagnati, Variarum observationum liber, Rome, G. Ferrarius for V. Accoltus, 1581.

29. Beate Gundert, “Zu den Quellen der Basler Galen-Ausgabe (1538)”, in Carl W. Müller, Christian Brockmann \& Wilhelm Brunschön (eds), Ärzte und ihre Interpreten. Medizinische Fachtexte der Antike als Forschungsgegenstand der Klassischen Philologie. Fachconferenz zu Ehren von Diethard Nickel, Munich and Leipzig, K. G. Saur, 2006, p. 81-100. 
30. Marie-Laure Monfort, Janus Cornarius et la redécouverte d'Hippocrate à la Renaissance, Turnhout, Brepols, 2018; Vivian Nutton, John Caius and the Manuscripts of Galen, Proceedings of the Cambridge Philological Society, Supplementary, vol. XIII, 1988.

31. Manardi, Ep.XIX-5, p. 192-193, suggesting also that earlier versions, as well as Avicenna, might preserve a better text.

32. Vivian Nutton, "Medicine and philology in Renaissance Paris", in Müller et al. (eds), Ärzte und ihre Interpreten, above, note 29, p. 49-59. Leonhard Fuchs complained in 1541 that few Greek scholars bothered or were competent enough to interest themselves in medical texts, Galeni De sanitate tuenda, Tübingen, U. Morhard, 1541, sig. A2v.

33. Stefania Fortuna, op. cit., note 20; Christina Savino, "Galenic Forgeries of the Renaissance: an Overview on Commentaries Falsely Attributed to Galen", in Bouras-Vallianatos \& Zipser, op. cit., note 21, p. 453-471.

34. Andreas Dudith, in Lorenz Scholz (ed.), Consiliorum et epistolarum medicinalium ....liber sextus, Frankfurt, Heirs of J. Aubrius, 1611, p. 44 (a letter of around 1579).

35. Conrad Gesner, Thesaurus Euonymi Philiatri de remediis secretis, liber physicus, medicus et partim chymicus..., Zurich, A. Gesner, 1554; Johann Guinther, De medicina veteri et nova, Basle, H. Petri, 1571; Thomas Mouffet, Nosomantica Hippocratea, sive Hippocratis prognostica cuncta, Frankfurt, Heirs of A. Wechel, C. Marnius and J. Aubrius, 1588.

Vivian Nutton, “The Reception of Fracastoro's Theory of Contagion. The Seed that Fell among Thorns?", Osiris, ser. 2, vol. VI, 1990.

36. Alessandro Arcangeli \& Vivian Nutton (eds), Girolamo Mercuriale. Medicina e Cultura nell'Europa del Cinquecento, Florence, Leo S. Olschki, 2008; Maria Kavvadia, Making Medicine in Post-Tridentine Rome: Girolamo Mercuriale's De arte gymnastica. A Different Reading of the Book. Ph.D. Diss., European University Institute, Florence, 2015.

37. Jean Fernel, Medicina, Paris, A Wechel, 1554, enlarged edition, Paris, A. Wechel, 1567. The therapeutic section also circulated separately from 1577 , and each of the three sections was given a separate title.

38. Nancy G. Siraisi, Avicenna in Renaissance Italy. The Canon and Medical Teaching in Italian Universities after 1500, Princeton, Princeton University Press, p. 142-160.

39. C. Donald O'Malley (ed.), The History of Medical Education, Los Angeles, University of California Press, 1970, p. 94; Ernst Giese \& Benno von Hagen, Geschichte der Medizinischen Fakultät der Friedrich-Schiller-Universität Jena, Jena, Fischer, 1958, p. 17-18.

40. Vivian Nutton, “The Reception of Fracastoro's Theory of Contagion. The Seed that Fell among Thorns?", Osiris, ser. 2, vol VI, 1990, p. 196-234; Concetta Pennuto, Simpatia, fantasia e contagio. Il pensiero medico e il pensiero filosofico di Girolamo Fracastoro, Rome, Edizioni di Storia e Letteratura, 2008.

41. Silvia De Renzi, Marco Bresadola \& Maria Conforti (eds.), Pathology in Practice: Diseases and Dissections in Early Modern Europe, London, Routledge, 2018.

42. Vivian Nutton, "Pieter van Foreest and the Plagues of Europe; some Observations on the Observationes", in H. L. Houtzager (ed.), Pieter van Foreest. Een Hollands medicus in de zestiende eeu, Amsterdam, Rodopi, 1989, p. 25-39; Gianna Pomata, "Sharing Cases: The Observationes in Early Modern Medicine", Early Science and Medicine vol. XV, 2010, p. 193-236.

43. Theodore Hagecius, Preface, to Laurentius Gryllus, Oratio de peregrinatione studii medicinalis ergo suscepta, Prague, G. Melantrich, 1566, sig. D ii r. 
44. Nicolò Massa, Epistolae medicinales et philosophicae, Venice, F. Bindoni and M. Pasini, 1550, fol. 58r.,

45. Andreas Vesalius, De humani corporis fabrica, Basle, J. Oporinus, 1543, p. 661

46. Vivian Nutton, Johann Guinter and Andreas Vesalius, Principles of Anatomy According to the Opinion of Galen, London and New York, Routledge, p. 42-44.

47. Daniel H. Garrison, Vesalius: The China Root Epistle. A New Translation and Critical Edition, Cambridge, Cambridge University Press, 2015, p. 47-53.

48. Daniel Margócsy, Mark Somos \& Stephen N Joffe, The Fabrica of Andreas Vesalius. A Worldwide Descriptive Census, Ownership and Annotations of the 1543 and 1555 Editions, Leiden and Boston, Brill, p. 72-73; Vivian Nutton,"The Anatomy of the Soul in Early Renaissance Medicine”, in Dunstan GR (ed.), The Human Embryo. Aristotle and the Arabic and European Traditions, Exeter, University of Exeter Press, 1990, p.136-157; id., "Wittenberg Anatomy", in Ole Grell \& Andrew Cunningham (eds), Medicine and the Reformation. London and New York, Routledge, 1993, p. 11-32; Jürgen Helm, "Religion and Medicine: Anatomical Education at Wittenberg and Ingoldstadt", in Jürgen Helm \& Annette Winkelmann (eds), Confessions and the Sciences in the Sixteenth Century, Leiden, Brill, p. 51-68.

49. Bjørn O. Skaarup, Anatomy and Anatomists in Early Modern Spain, Farnham and Burlington, Ashgate, 2015.

50. Vivian Nutton, "Vesalius in England, 1544 to 1547", in Robrecht Van Hee (ed.), In the Shadow of Vesalius, Antwerp and Apeldoorn, Garant, 2020, p. 93-100.

51. Ibid., p. 95.

52. Bjørn O. Skaarup, op. cit., p. 98-105.

53. C. Donald O'Malley, The History of Medical Education, Los Angeles, University of California Press, 1970, p. 94.

54. Howard M. Adelmann, Marcello Malpighi and the Evoiution of Embryology, Ithaca, Cornell University Press, 1996, p. 86-7.

55. Antonio Musa Brasavola, op. cit., note 25, p. 211.

56. Adam Landau, Preface to Laurentius Gryllus, De sensu, Prague, G. Melantrich, 1566, sig.: B iii v.

57. David Wootton, Bad Medicine: Doctors doing Harm since Hippocrates, Oxford, Oxford University Press, 2007.

\section{ABSTRACTS}

The phrase "medical humanism" has been often used over the past fifty years to refer to the learned medicine of the Late Renaissance. But it can refer to several different aspects of this period, including a general reference for classical antiquity or a more specific reference to a reliance on ancient, and primarily Greek texts. This paper attempts to tease out some of the ways in which this classical heritage was used at different times in a plea for a greater precision. 
L'expression « humanisme médical » a souvent été utilisée, dans les cinquante dernières années, pour désigner la médecine érudite de la fin de la Renaissance. Mais elle peut s'appliquer à différents aspects de cette période, en désignant la référence à l'antiquité classique, ou spécifiquement la dépendance envers les textes antiques, particulièrement en grec. En tentant d'exposer certains des usages de l'héritage classique à différents moments de la Renaissance, cet article offre un plaidoyer pour davantage de précision.

\section{INDEX}

Mots-clés: humanisme médical, anatomie, Galien, Vésale, Fracastor, botanique, Leoniceno, humanisme

Keywords: medical humanism, anatomy, Galen, Vesalius, Fracastoro, Harvey, botany, Leoniceno, humanism

\section{AUTHOR}

\section{VIVIAN NUTTON}

University College London 